\title{
EFFECT OF BI RATE, INFLATION, EXCHANGE, AND THE DOW JONES AGAINST COMPOSITE STOCK PRICE INDEX (CSPI \\ CASE STUDY IN 2009-2014)
}

\author{
Tuti Purwaningsih \\ Study of Development Economics Faculty of Economics and Business-UMM \\ tutipurwaningsih1@gmail.com
}

\begin{abstract}
The purpose of this study was to determine the influence of the independent variables are indicated by the BI Rate, the rate of inflation, exchange rate and the Dow Jones Against Composite Stock Price Index. The analysis tool used is multiple linear regression using time series data is 2009-2014. In the model equations, Composite Stock Price Index is the dependent variable and the BI Rate, the rate of inflation, exchange rates as well as Dow Jones is the independent variable. Results of regression is that the variable BI Rate (X1) a significant negative effect on the Composite Stock Price Index, inflation (X2) significant negative effect on the Composite Stock Price Index, the exchange rate (X3) significant negative effect on Stock Price Index and Index Dow Jones (X3) positive and significant impact on the Composite Stock Price Index. The coefficient of determination (R2) is 0.970445, or 97\%. This indicates that the BI Rate (X1), the rate of inflation (X2), the exchange rate (X3) and Dow Jones (X4) in explaining the dependent variable or dependent Composite Stock Price Index amounted to 97\%, while the remaining 3\% is explained by other variables outside the model that implicitly reflected in confounding variables.Suggestions can meet of the results of this study are advised to look at the effect of other macroeconomic variables in detail which can affect and use other variables outside the monetary variables like social and political situation of a country. And also advised to conduct research using other approaches.
\end{abstract}

Keywords: Composite Stock Price Index, BI Rate, Inflation, Exchange, Dow Jones.

\begin{abstract}
ABSTRAK
Tujuan dari penelitian ini adalah untuk mengetahui pengaruh variabel independen ditunjukkan dengan BI Rate, tingkat inflasi, nilai tukar dan Indeks Terhadap Harga Saham Gabungan Dow Jones. Alat analisis yang digunakan adalah regresi linier berganda dengan menggunakan data time series adalah 2009-2014. Dalam persamaan model, Indeks Harga Saham Gabungan adalah variabel dependen dan BI Rate, tingkat inflasi, nilai tukar serta Dow Jones adalah variabel independen. Hasil regresi adalah bahwa variabel BI Rate (X1) berpengaruh negatif signifikan terhadap Indeks Harga Saham Gabungan, inflasi
\end{abstract}


(X2) berpengaruh negatif signifikan terhadap Indeks Harga Saham Gabungan, nilai tukar (X3) berpengaruh negatif signifikan terhadap Indeks Harga Saham dan Indeks Dow Jones (X3) berpengaruh positif dan signifikan terhadap Indeks Harga Saham Gabungan. Koefisien determinasi (R2) adalah 0,970445, atau 97\%. Hal ini menunjukkan bahwa BI Rate (X1), tingkat inflasi (X2), nilai tukar (X3) dan Dow Jones (X4) dalam menjelaskan variabel dependen atau Indeks bergantung Harga Saham Gabungan sebesar 97\%, sedangkan sisanya $3 \%$ dijelaskan oleh variabel lain di luar model yang secara implisit tercermin dalam variabel pengganggu. Saran dapat memenuhi hasil penelitian ini disarankan untuk melihat pengaruh variabel makroekonomi lainnya secara detail yang dapat mempengaruhi dan menggunakan variabel lain di luar variabel moneter seperti situasi sosial dan politik suatu negara. Dan juga disarankan untuk melakukan penelitian menggunakan pendekatan lain.

Kata Kunci : Indeks Harga Saham Gabungan, BI Rate, Inflasi, Exchange, Dow Jones.

\section{PENDAHULUAN}

Investasi di pasar modal bagi investor masih memberikan potensi keuntungan sangat tinggi. Pasar modal merupakan salah satu alternatif pilihan investasi yang dapat menghasilkan tingkat keuntungan optimal bagi investor. Investasi dapat diartikan sebagai suatu kegiatan menempatkan dana pada satu atau lebih dari satu aset selama periode tertentu dengan harapan dapat memperoleh penghasilan dan memperoleh peningkatan nilai dari investasi. (Hismendi, 2013)

Pasar Modal memiliki peran bagi perekonomian suatu negara karena pasar modal menjalankan dua fungsi, yaitu pertama sebagai sarana bagi pendanaan usaha atau sebagai sarana bagi perusahaan untuk mendapatkan dana dari masyarakat pemodal atau investor. (Pasaribu, 2014)

Dana yang diperoleh dari pasar modal dapat digunakan untuk pengembangan usaha, ekspansi, penambahan modal kerja dan lainlain. Pasar modal menjadi sarana bagi masyarakat untuk berinvestasi pada segi keuangan seperti saham, obligasi, reksa dana, dan lain-lain. Dengan demikian, masyarakat dapat menempatkan dana yang dimilikinya tersebut sesuai dengan karakteristik keuntungan masing-masing segi keuangan yang diminati. Kegiatan investasi adalah suatu kegiatan 
menanamkan modal baik langsung maupun tidak langsung dengan harapan pada waktunya nanti pemilik modal mendapatkan sejumlah keuntungan dari hasil penanaman modal tersebut. Bagi para investor, melalui pasar modal dapat memilih obyek investasi dengan berbagai ragam tingkat pengembalian dan tingkat risiko yang dihadapi, sedangkan bagi para penerbit (issuers atau emiten) melalui pasar modal dapat mengumpulkan dana jangka panjang untuk menunjang kelangsungan usaha. Salah satu kegiatan investasi yang dapat dipilih oleh investor adalah berinvestasi di pasar modal. Di Indonesia, investor yang berminat untuk berinvestasi di pasar modal dapat berinvestasi di Bursa Efek Indonesia (BEI). Bursa Efek Indonesia sendiri merupakan penggabungan dari Bursa Efek Jakarta dan Bursa Efek Surabaya pada tanggal 1 Desember 2007. Penggabungan ini dilakukan demi efisiensi dan efektivitas operasional dan transaksi. (Fitriawati, 2009)

Untuk memberikan informasi yang lebih lengkap bagi investor tentang perkembangan bursa, BEI menyebarkan data pergerakan harga saham melalui media cetak dan elektronik. Satu indikator pergerakan harga saham tersebut adalah indeks harga saham. Saat ini, BEI mempunyai tujuh macam indeks saham (www.idx.co.id) seperti Indeks Harga Saham Gabungan (IHSG), Indeks Sektoral, Indeks LQ 45, Jakarta Islmic Index (JII), Indeks Kompas 100, Indeks BISNIS-27, Indeks PEFINDO 25, Indeks SRIKEHATI, Indeks Papan Utama, Indeks Papan Pengembangan, Indeks Individual.

Salah satu indeks yang sering diperhatikan investor ketika berinvestasi di Bursa Efek Indonesia adalah Indeks Harga Saham Gabungan. Hal ini disebabkan indeks ini berisi atas seluruh saham yang tercatat di Bursa Efek Indonesia. Oleh karena itu melalui pergerakan indeks harga saham gabungan, seorang investor dapat melihat kondisi pasar apakah sedang bergairah atau lesu. Perbedaan kondisi pasar ini tentu memerlukan strategi yang berbeda dari investor dalam berinvestasi. Banyak faktor 
yang dapat mempengaruhi indeks saham, antara lain perubahan tingkat suku bunga Bank Sentral, keadaan ekonomi global, tingkat harga energi dunia, kestabilan politik suatu negara, dll. (Pasaribu, 2014, 10) Beberapa variabel yang sering digunakan dalam melakukan analisis ekonomi makro antara lain BI rate, tingkat inflasi, jumlah uang beredar, tingkat kurs rupiah, pendapatan masyarakat dan lain-lain. BI rate merupakan salah satu instrument moneter sebagai cerminan sikap atau respon kebijakan moneter yang ditetapkan oleh Bank Indonesia dan patokan bagi bank atau lembagalembaga keuangan lainnya di Indonesia dalam menentukan suku bunga pinjaman.

Menurut (Halim, 2005), BI rate mempengaruhi resiko saham, hal ini disebabkan oleh adanya keinginan seorang investor dalam memilih alternatif investasi akan cenderung memilih pada aktivitas investasi yang menguntungkan, jika BI rate lebih tinggi daripada return saham maka akan lebih menguntungkan memilih investasi yang bebas resiko seperti menyimpan uang di Bank Indonesia daripada investasi yang penuh resiko seperti saham. Ketika BI rate mengalami kenaikan maka return atau tingkat pengembalian atas saham akan cenderung rendah. Dan $\mathrm{BI}$ rate yang cenderung naik maka pergerakan IHSG akan menurun karena banyak masyarakat atau calon investor akan cenderung menabung ke sektor perbankan atau menyimpan dana di Bank Indonesia. Selain BI rate, tingkat inflasi merupakan variabel ekonomi makro yang paling penting karena dapat membawa pengaruh buruk pada struktur biaya produksi dan tingkat kesejahteraan. Bahkan satu rezim kabinet pemerintahan dapat jatuh hanya karena tidak dapat menekan dan mengendalikan lonjakan tingkat inflasi. Laju kenaikan tingkat inflasi dipengaruhi oleh beberapa faktor seperti adanya peningkatan jumlah uang beredar. Tingkat inflasi meningkat maka investor atau masyarakat banyak menanamkan modalnya pada sektor riil atau perusahaan bahkan membeli perusahaan baru yang sekiranya menguntungkan, hal ini berpengaruh terhadap pergerakan IHSG bisa jadi 
positif dan bisa jadi negatif karena mayoritas investor akan membeli perusahaan misalnya melalui saham perusahaan di pasar modal. Salah satu faktor yang mempengaruhi pergerakan saham lainnya adalah nilai kurs. (Ardian, 2010)

Nilai kurs juga mempengaruhi resiko saham. Perubahan nilai kurs timbul apabila terdapat perubahan kurs antara pos transaksi dan penyelesaian pos moneter yang timbul dari transaksi dalam mata uang asing. Tingkat keuntungan yang diharapkan dari adanya investasi akan menurun dengan cepat jika nilai kurs berubah tajam, sehingga bagi para pelaku ekonomi semakin rendah tingkat perubahan nilai kurs adalah semakin baik.

Hal ini akan mempengaruhi keputusan seorang investor dalam berinvestasi. Seorang investor akan menanamkan modalnya pada perusahaan yang mempunyai kinerja yang cukup baik karena dapat meningkatkan nilai kekayaan dan pengembalian dana bagi pememgang sahamnya. Kurs mata uang rupiah terhadap dollar melemah maka dampaknya terhadap IHSG adalah bisa jadi berpengaruh baik dan buruk, perusahaan asing bisa jadi keluar bahkan masuk karena adanya kurs yang melemah dalam artian kurs melemah justru angkanya naik. Nilai kurs yang semakin melemah juga mempengaruhi munculnya atau terjadi permasalahan ekonomi. (Fitriawati, 2009)

Faktor lain seperti saham asing yaitu Indeks Dow Jones yang menjadi patokan dalam pergerakan saham lokal maupun salam dari Negara-negara lain yang terdaftar di Bursa Efek Indonesia mempengaruh Indeks Harga Saham Gabungan. Sehingga pengaruh dari Indeks Dow Jones dapat mempengaruhi dan memotivasi investor dalam kebijakan alokasi dana. Bursa asing kini telah hadir dalam bentuk dua sisi bagi para manajer investasi di Indonesia yaitu bentuk tantangan kebijakan alokasi dana dan bentuk peluang ekulibrium risiko dan tingkat pengembalian instrument investasi alternatif. (Pasaribu, 2014)

Disamping pengetahuan tentang faktor fundamental BI rate dan inflasi, tambahan pertimbangan lain bagi investor adalah indikator 
kegiatan di bursa yang diterjemahkan dalam bentuk Indeks Harga Saham Gabungan (IHSG). Apabila IHSG berada pada angka yang cukup tinggi, maka hal ini dapat diartikan kondisi pasar sedang dalam keadaaan ramai, sedangkan sebaliknya bila indeksnya rendah atau menurun maka bisa diartikan pasar dalam keadaan lesu.

Karena globalisasi pasar modal, maka calon investor dan perusahaan penerbit (issuer) pada tahap emisi saham baru tidak hanya melakukan transaksi dalam ruang lingkup yang terbatas. Indeks bursa asing atau internasional memiliki pengaruh yang signifikan terhadap tingkat pengembalian indeks saham Indonesia. Namun bursa saham internasional atau indeks tertentu berimplikasi negatif dan berpengaruh terhadap Indeks Harga Saham Gabungan dalam jangka pendek. (Fitriawati, 2009, 29).

\section{Hubungan Antar Variabel}

Seperti yang telah diungkapkan di atas, banyak faktor yang mempengaruhi Indeks Harga Saham Gabungan. Faktor-faktor tersebut bisa dari internal maupun eksternal.
Investor tentu harus memperhatikan faktor-faktor tersebut agar investasi seperti yang dilakukannya dapat memberikan hasil yang diharapkan. Banyak penelitian yang telah dilakukan untuk mengetahui faktorfaktor apa sajakah yang berpengaruh terhadap Indeks Harga Saham Gabungan.

Pada penelitian ini faktor-faktor yang diduga berpengaruh terhadap Indeks Harga Saham Gabungan (IHSG) adalah BI rate, tingkat inflasi, kurs jual rupiah terhadap dollar, indeks bursa asing. Variabel tersebut dipilih karena adanya ketidak konsistenan dalam penelitian-penelitian terdahulu dan adanya anomali dari data yang telah diamati seperti yang telah diungkapkan terdahulu.

Berikut ini akan dijelaskan hubungan antara variabel-variabel independen yang digunakan dalam penelitian ini dengan variabel dependen:

\section{Hubungan BI rate Terhadap IHSG \\ Pada tahun 2005, ketidakstabilan makro-ekonomi mengharuskan pemerintah dan Bank Indonesia (BI) mengambil beberapa kebijakan}


dalam upaya menjaga proses pemulihan ekonomi nasional. BI menempuh suatu langkah-langkah pengetatan moneter melalui penerapan kerangka kebijakan moneter baru dengan Inflation Targeting Framework (ITF) yang ditandai dengan pengumuman target inflasi beberapa periode ke depan kepada publik.

Tujuan utama dari kebijakan moneter ini adalah inflasi yang rendah dan stabil (www.bi.go.id). Untuk itu, BI mulai menggunakan BI rate sebagai sinyal kebijakan moneter sejak Juli 2005, dimana pada periode sebelumnya kerangka kerja operasional moneter masih menggunakan uang primer sebagai sasaran operasionalnya.

Menurut Bank Indonesia (www.bi.go.id), "BI rate adalah suku bunga instrumen sinyaling Bank Indonesia yang ditetapkan pada Rapat Dewan Gubernur (RDG) triwulan untuk berlaku selama triwulan berjalan, kecuali ditetap-kan berbeda oleh RDG bulanan dalam triwulan yang sama".

BI rate merupakan cerminan sikap atau respon kebijakan moneter yang ditetapkan BI dan patokan bagi bank dan/atau lembaga-lembaga keuangan lainnya di Indonesia dalam menentukan suku bunga pinjaman atau suku bunga simpanan. Patokan yang dimaksud hanya sebatas pada rujukan dan bukan peraturan yang bersifat mengikat atau memaksa. Bagi BI sendiri, BI rate merupakan suku bunga yang akan disalurkan kepada bank-bank konvensional di Indonesia.

Setiap terjadinya kenaikan pada BI rate dapat dipastikan akan berdampak negatif terhadap iklim investasi di pasar modal. Biasanya para investor lebih cenderung untuk mengalihkan investasinya di pasar modal ke deposito-deposito di dunia perbankan. Hal ini mengingat naiknya BI rate akan berdampak juga terhadap kenaikan tingkat suku bunga deposito perbankan. Dengan kata lain, BI rate memiliki pengaruh terhadap Indeks Harga Saham Gabungan dan saham-saham lainnya.

Hubungan Tingkat Inflasi terhadap IHSG

Meningkatnya laju inflasi akan menyebabkan para investor enggan untuk menginvestasikan 
dananya dalam bentuk saham, mereka cenderung untuk memilih investasi dalam bentuk logam mulia atau real estate, jenis ini dapat melindungi investor dari kerugian yang disebabkan inflasi. Dari hasil penelitian Ardian (2010) diperoleh hasil bahwa memang secara jangka pendek, meningkatnya inflasi akan menyebabkan penurunan angka indeks harga saham gabungan atau berpengaruh negatif, namun dalam jangka panjang, justru kenaikan inflasi, justru akan meningkatkan indeks harga saham gabungan.

Secara parsial tingkat inflasi tidak berpengaruh signifikan terhadap indeks harga saham gabungan baik dalam jangka pendek atau pun jangka panjang. Dengan kata lain, pada jangka panjang, kenaikan inflasi akan menurunkan capital gain yang menyebabkan berkurangnya keuntungan yang diperoleh investor. Di sisi perusahaan, terjadinya peningkatan inflasi, dimana peningkatannya tidak dapat dibebankan kepada konsumen, dapat menurunkan tingkat pendapatan perusahaan. Hal ini berarti risiko yang akan dihadapi perusahaan akan lebih besar untuk tetap berinvestasi dalam bentuk saham, sehingga permintaan terhadap saham menurun.

\section{Hubungan Kurs Rupiah terhadap dollar dengan IHSG}

Bagi investor depresiasi rupiah terhadap dollar menandakan bahwa prospek perekonomian Indonesia suram. Sebab depresiasi rupiah dapat terjadi apabila faktor fundamental perekonomian Indonesia tidaklah kuat. Hal ini tentunya menambah resiko bagi investor apabila hendak berinvestasi di bursa saham Indonesia. Investor tentunya akan menghindari munculny resiko, sehingga investor akan cenderung melakukan aksi jual dan menunggu hingga situasi perekonomian dirasakan membaik. Aksi jual yang dilakukan investor ini akan mendorong penurunan indeks harga saham di BEI.

Nilai kurs yang melemah mengakibatkan adanya peningkatan indeks saham di pasar saham terutama indeks saham asing yang mana pada indeks asing terjadi aktifasi di bursa efek, sementara pada kondisi kurs naik maka indeks saham 
gabungan akan mengalami penurunan sehingga menjadikan investor asing memiliki ketertarikan untuk membeli perusahan lokal di pasar saham lokal.

\section{Hubungan Indeks Dow Jones} Terhadap IHSG

Indeks Dow Jones merupakan salah satu dari 3 indeks utama di Amerika Serikat. Indeks yang lain adalah Nasdaq Composite dan Standard and Poor's 500. Indeks ini merepresentasikan dari kegiatan perekonomian di Amerika Serikat. Indeks ini dapat menggambarkan mengenai bagaimana performa perekonomian Amerika. Perusahaan yang tercatat di Indeks Dow Jones merupakan perusahaan besar yang telah beroperasi secara global.

Dengan adanya peningkatan Indeks Dow Jones ini berarti kinerja perekonomian Amerika Serikat ikut membaik. Sebagai salah satu negara tujuan ekspor di Indonesia, pertumbuhan ekonomi Amerika Serikat dapat mendorong pertumbuhan ekonomi Indonesia melalui kegiatan ekspor maupun aliran modal masuk baik investasi langsung maupun melalui pasar modal. Indeks Dow Jones yang mengalami kenaikan maka mempengaruhi pergerakan Indeks Harga Saham Gabungan sehingga kondisi IHSG tersebut dapat menarik calon investor bergabung dalam pasar saham dan melakukan investasi maksimal sehingga dapat meningkatkan return pengembalian saham yang lebih baik.

\section{METODE PENELITIAN}

\section{Jenis Penelitian}

Jenis penelitian yang dilakukan adalah studi deskriptif kuantitatif terhadap Indeks Harga Saham Gabungan pada Bursa Efek Indonesia serta faktor-faktor yang mempengaruhinya.

\section{Jenis Data dan Sumber Data}

1. Jenis Data

Jenis data yang digunakan dalam penelitian ini adalah data sekunder berupa IHSG, BI rate, tingkat inflasi, kurs dan Indeks Dow Jones periode Januari sampai dengan Desember tahun 2009- 2014.

2. Sumber Data

Sumber data yang digunakan dalam penelitian ini berasal dari data yang telah diterbitkan oleh Bank 
Sentral Indonesia (BI), Bursa Efek

Indonesia (BEI), dan www.bi.go.id

\section{Teknik Pengumpulan Data}

Dalam penelitian ini data yang diperoleh dikumpulkan dengan cara dokumentasi dilakukan di pojok BEI berupa data Indeks Harga Saham Gabungan. Selain itu pengumpulan data dan informasi dilakukan dengan cara mengambil dari internet, artikel, jurnal, tesis dan mempelajari dari buku-buku pustaka yang mendukung proses penelitian ini.

\section{Definisi Operasional Variabel}

Pengertian dari masing - masing variabel yang digunakan dalam penelitian ini adalah:

1. Variabel Indeks Harga Saham Gabungan (IHSG) merupakan jumlah nilai pasar dibagi dengan total saham yang tercatat. Pengukurannya yaitu :

$$
\mathrm{IHSG}=\frac{\Sigma\left(P_{S} x S_{S}\right)}{\Sigma\left(P_{\text {base }} x S_{S}\right)}
$$

2. Variabel BI rate merupakan suku bunga yang diteetapkan oleh Bank Indonesia sebagai implementasi kebijakan moneter pada operasi moneter yang dilakukan Bank Indonesia melalui pengelolaan likuiditas (liquidity management) di pasar uang untuk mencapai sasaran operasional kebijakan moneter

3. Variabel Kurs merupakan nilai tukar rupiah terhadap dollar Amerika Serikat menurut Bank Indonesia. Pengukurannya yaitu Kurs tengah $=\frac{\text { Kurs jual }+ \text { Kurs beli }}{2}$

4. Variabel Tingkat inflasi merupakan meningkatnya harga secara umum dan terus menerus. Dimana indeks harga konsumen tahun dasar dikurangi Indeks harga konsumen pada tahun berikutnya dibagi indeks harga konsumen pada tahun berikutnya dikali $100 \%$.

Pengukurannya yaitu :

$$
\text { Inflasi }=\frac{I H K_{n}-I H K_{n-1}}{I H K_{n-1}} \times 100 \%
$$

5. Variabel indeks bursa asing Indeks Dow Jones periode Januari 2009 sampai dengan Desember tahun 2014 merupakan bursa asing yang memiliki pengaruh signifikan.

$$
\text { Indeks Dow Jones }=\frac{p}{\text { Divisor }}
$$

\section{Teknik Analisa Data Persamaan}

\section{Garis Regresi}

Penelitian ini menggunakan metode kuantitatif dengan alat analisis regresi berganda. Analisis 
regresi berganda digunakan untuk menguji pengaruh antara BI rate, tingkat inflasi, kurs, dan bursa asing terbaik terhadap IHSG. Seberapa besar variabel tersebut saling mempengaruhi yaitu dapat dihitung dengan menggunakan persamaan regresi berganda sebagai berikut

$\log Y=a+b_{1} X_{1}+b_{2} X_{2}+b_{3} \log X_{3}+$ $b_{4} \log X_{4}+e$

Keterangan :

Log $Y=$ Indeks Harga Saham Gabungan (IHSG)

a = konstanta

$b_{1} b_{2} b_{3} b_{4}=$ koefisien garis regresi

$X_{1} \quad=$ BI rate

$X_{2} \quad=$ tingkat inflasi

$\log X_{3}=$ kurs

$\log X_{4} \quad=$ Indeks Dow Jones

$e \quad=$ standard error

\section{Pengujian Hipotesis}

Untuk menguji kebenaran hipotesis, dalam penelitian ini menggunakan uji hipotesis sebagai berikut:

Pengujian hipotesis secara partial (uji t)

Pengujian dilakukan untuk mengetahui secara partial apakah variabel independen berpengaruh secara signifikan atau tidak terhadap variabel independen. Pengujian ini dilakukan dengan uji dua arah dengan hipotesa:

Ho : $\beta i=0$, artinya tidak terpengaruh secara signifikan dari variabel independen terhadap variabel dependen.

Ha : $\beta i \neq 0$, artinya ada pengaruh secara signifikan dari variabel independen terhadap variabel dependen.

Untuk menghitung nilai $t_{\text {hitung }}$ digunakan rumus:

thitung $=\frac{\beta i}{S e(\beta i)}$

dimana: $\quad \beta i=$ Koefisien kolerasi

$\operatorname{Se}(\beta i)=$ Standar error koefisien regresi. Dengan kriteria pengujian:

1). Ho diterima dan $\mathrm{Ha}$ ditolak apabila $t_{\text {hitung }}<t_{\text {tabel, }}$ artinya variabel independen tidak berpengaruh secara signifikan terhadap variabel dependen.

2). Ho ditolak dan $\mathrm{Ha}$ diterima apabila $t_{\text {hitung }}>t_{\text {tabel, }}$ artinya variabel independen berpengaruh secara signifikan terhadap variabel dependen

\section{Pengujian secara bersama-sama} (uji F) 
Pengujian dilakukan secara bersama-sama variabel independen berpengaruh secara signifikan atau tidak terhadap variabel dependen. Pengujian ini dilakukan uji dua arah dengan hipotesa:

Ho : $\beta_{1}=\beta_{2}=\beta_{3}=\beta_{4}$ artinya tidak terpengaruh secara signifikan dari variabel independen terhadap variabel dependen secara bersamasama.

Ha : $\beta_{1} \neq \beta_{2} \neq \beta_{3} \neq \beta_{4}$ artinya terdapat pengaruh signifikan dari variable independen terhadap variabel dependen secara bersama-sama. Untuk menentukan $F_{\text {hitung }}$ dengan menggunakan rumus:

$$
\begin{aligned}
F \text { hitung }= & \frac{\text { MSS dari } E S S}{M S S \text { dari } R S S} \\
& =\frac{\frac{R^{2}}{k-1}}{\left(1-R^{2}\right) /(n-k)}
\end{aligned}
$$

dimana:
MSS :Jumlah kuadrat yang dijelaskan

ESS : Jumlah kuadrat residual

$\mathrm{R}^{2} \quad$ : Koefisien determinasi

n : Jumlah observasi

k : Jumlah variabel

Kriteria pengujian:

1). Ho diterima dan $\mathrm{Ha}$ ditolak apabila $\mathrm{F}_{\text {hitung }}<\mathrm{F}_{\text {tabel, }}$ artinya variabel independen tidak berpengaruh secara signifikan terhadap variabel dependen.

2). Ho ditolak dan $\mathrm{Ha}$ diterima apabila $F_{\text {hitung }}>F_{\text {tabel, }}$ artinya variabel independen berpengaruh secara signifikan terhadap variabel dependen.

\section{Koefisien Determinasi (R-Squared)}

Koefisien determinasi ini menggambarkan tingkat hubungan antara satu atau beberapa variabel bebas dengan terikat. $\mathrm{R}^{2}$ merupakan besaran non negatif, batasnya adalah $0 \leq \mathrm{R}^{2} \leq 1$. Suatu $\mathrm{R}^{2}$ sebesar 1 berarti terjadi hubungan sempurna, sedangkan $\mathrm{R}^{2}$ yang bernilai 0 berarti tidak ada hubungan antara variabel terikat dengan variabel bebas, dengan demikian semakin kecil $\mathrm{R}^{2}$ semakin lemah hubungan antar variabel.

\section{Pengujian Asumsi Klasik}

Penggunaan analisis regresi linear berganda memerlukan uji asumsi klasik atau uji persyaratan analisis regresi linear berganda sehingga persamaan garis regresi yang diperoleh benar-benar dapat digunakan untuk memprediksi variabel dependent. Uji persyaratan 
tersebut harus terpenuhi, apabila tidak maka akan menghasilkan garis regresi yang tidak cocok untuk memprediksi. Pengolahan data penelitian ini menggunakan eviews 4.1. Pengujian asumsi klasik meliputi uji autokorelasi, heteroskedastisitas, normalitas, dan multikolinieritas.

\section{Uji Autokorelasi}

Uji ini bertujuan untuk menguji apakah dalam suatu model regresi linier ada korelasi ada kesalahan pengganggu pada periode $\mathrm{t}$ dengan kesalahan pada periode t-1. Jika terjadi korelasi maka terdapat problem autokorelasi, korelasi muncul karena observasi yang berurutan sepanjang waktu berkaitan satu sama lain, masalah ini timbul karena residual (kesalahan pengganggu) tidak bebas dari observasi ke observasi lain.

Salah satu cara untuk mendeteksi ada atau tidaknya autokrelasi pada model dinamis autoregressive yaitu dengan cara Durbin $h$ Test atau statistik $h$ dengan formula sebagai berikut:

$h=\hat{p} \sqrt{\frac{n}{1-n\left[\operatorname{Var}\left(a_{2}\right)\right]}}$
Untuk mendeteksi adanya autokorelasi padal model dinamis autoregressive yaitu dengan uji $h$ Durbin Watson statistik dengan hipotesis sebagai berikut:

$\mathrm{H}_{\mathrm{o}}=$ tidak terdapat autokorelasi dalam model autoregressive $\mathrm{H}_{1}=$ terdapat autokorelasi dalam model autoregressive

Dengan derajat kepercayaan $\alpha=5 \%$ dan kriteria pengujian:

$\mathrm{H}_{\mathrm{o}}$ ditolak dan $\mathrm{H}_{1}$ diterima jika $h_{\text {hitung }}$ $>h_{\text {tabel }}$

$\mathrm{H}_{\mathrm{o}}$ diterima dan $\mathrm{H}_{1}$ ditolak jika $h_{\text {hitung }}$ $<h_{\text {tabel }}$

Adapun ketentuan penolakan dan penerimaan $\mathrm{H}_{0}$ :

a. Jika du $<$ DW statistik < 4-du maka tidak terjadi autokorelasi atau $\rho=0$

b. Jika DW statistik < dl maka terjadi autokorelasi positif atau $\rho$ $=(+)$

c. Jika dl < DW statistik < 4-dl maka pengujian tidak bisa disimpulkan (inclusive)

d. Jika 4-du < DW statistik < 4-dl maka pengujian tidak bisa disimpulkan (inclusive) 
e. Jika DW statistik > 4-dl maka terjadi autokorelasi negatif atau $\rho$ $=(-)$

\section{Uji Heterokedastisitas}

Uji ini bertujuan untuk menguji apakah dalam model regresi terjadi ketidaksamaan varian dari residual satu pengamatan ke pengamatan yang lain. Tetap akan disebut sebagai homoskedastisitas dan jika hal itu berbeda maka akan disebut heterokedastisitas. Model regresi yang baik adalah yang tidak terjadi heterokedastisitas.

Salah satu cara untuk mendeteksinya yaitu dengan metode uji park. Metode uji park yaitu dengan cara meregresikan nilai residual $\log \left(\right.$ resid $\left.^{2}\right)$ dengan masingmasing dari variabel tersebut independent. Dengan hipotesis sebagai berikut:

$\mathrm{H}_{\mathrm{o}}=$ tidak terdapat atau dipeoleh heterokedastisitas dalam model autoregressive

$\mathrm{H}_{1}=$ terdapat heterokedastisitas dalam model autoregressive

Kriteria tersebut dipenuhi dengan membandingkan nilai probabilitas pada setiap variabel independen pada hasil uji park dengan nilai derajat kepercayaan $\alpha=$ 5\%. Dengan kriteria pengujian apabila nilai probabilitas semua variabel independent diatas $\alpha=5 \%$ maka $\mathrm{H}_{\mathrm{o}}$ diterima, dan apabila salah satu nilai probabilitas variabel independen dibawah $\alpha=5 \%$ maka $\mathrm{H}_{1}$ diterima.

\section{Uji Multikolinieritas}

Uji ini bertujuan untuk menguji apakah model regresi ditemukan adanya korelasi antar variabel bebas, dimana model regresi yang baik seharusnya tidak terjadi tidak ortogonal. Untuk mendeteksi ada atau tidaknya multikolineritas didalam model regresi adalah dapat menganalisis korelasi variabelvariabel bebas dengan matrik korelasi, jika antar variabel bebas ada korelasi yang cukup tinggi (umumnya diatas 0,90 ) maka hal ini menunjukan adanya indikasi multikolinieritas.

\section{Hasil Penelitian Dan Pembahasan}

Untuk mendapat hasil regresi antara variabel bebas (BI Rate, tingkat inflasi, kurs dan Indeks Dow Jones) dan variabel terikat (Indeks Harga Saham Gabungan) maka digunakan data sekunder yang 
bersumber dari Bank Indonesia yang dicatat mulai dari tahun 2009 sampai dengan tahun 2014 dalam bentuk persen dan dapat diolah dengan menggunakan program Eviews 4. Berdasarkan data yang diperoleh dari hasil penelitian yaitu data yang telah diolah kedalam model melalui program Eviews 4.1. Hasil estimasi tersebut dalam tabel berikut ini :

Pada hasil estimasi diatas, maka dapat disusun persamaan model sebagai berikut :

$\log \mathrm{Y}=\alpha+\mathrm{b}_{1} \mathrm{X}_{1}+\mathrm{b}_{2} \mathrm{X}_{2}+\mathrm{b}_{3} \mathrm{LX}_{3}+\mathrm{b}_{4} \mathrm{LX}_{4}$ $\mathrm{Y}=0.257754-0.026240 \mathrm{X} 1-0.004654$

X2 - 0.653985 X3 + 1.492418 X4

Dari hasil estimasi diatas maka dapat dianalisis sebagai berikut :

\section{Analisis Koefisiean Regresi}

$\alpha$ : Intercept atau konstanta bernilai positif 0.257754, yang berarti besarnya nilai IHSG (Log Y) sebesar 0.257754 pada saat variabel bebas BI rate (X1), inflasi (X2), kurs (Log X3) dan indeks Dow Jones (Log X4) adalah nol/konstan.

$\mathrm{b}_{1}$ : Koefisien variabel tingkat BI rate (X1) adalah sebesar - 0.026240 . Hal ini menunjukkan pengaruh negatif antara BI Rate (X1) terhadap Indeks Harga Saham Gabungan sebesar - $0.026240 \%$. Kondisi ini menunjukkan setiap kenaikan BI Rate sebesar 1\% maka Indeks Harga Saham Gabungan akan turun sebesar - $0.026240 \%$ dengan asumsi variabel yang lain tetap.

$\mathrm{b}_{2}$ : Koefisien tingkat inflasi (X2) adalah sebesar - 0.004654, hal ini menunjukkan pengaruh negatif tingkat inflasi (X2) terhadap Indeks Harga Saham Gabungan sebesar $0.004654 \%$. Kondisi ini menunjukkan setiap kenaikan tingkat inflasi sebesar 1\% maka Indeks Harga Saham Gabungan akan turun sebesar - $0.004654 \%$ dengan asumsi variabel yang lain tetap.

$\mathrm{b}_{3}$ : Koefisien kurs $(\log$ X3) adalah memiliki nilai sebesar -0.653985 , hal ini menunjukkan pengaruh negatif kurs (Log X3) terhadap Indeks Harga Saham Gabungan sebesar - 0.653985 $\%$. Kondisi ini menunjukkan setiap kenaikan kurs sebesar 1\% maka Indeks Harga Saham Gabungan akan turun sebesar - $0.653985 \%$ dengan asumsi variabel yang lain tetap.

$\mathrm{b}_{4}$ : Koefisien Indeks Dow Jones (Log X4) adalah sebesar 1.492418, hal ini menunjukkan pengaruh positif (X2) terhadap Indeks Harga Saham 
Gabungan sebesar $1.492418 \%$.

Kondisi ini menunjukkan setiap kenaikan tingkat inflasi sebesar $1 \%$ maka Indeks Harga Saham Gabungan akan naik sebesar $1.492418 \%$ dengan asumsi variabel yang lain tetap.

\section{Uji Kesesuaian Hipotesis}

Uji kesesuaian hipotesis ini dilakukan untuk mengetahui kebenaran dari hipotesis tentang pengaruh variabel independent terhadap variabel dependent. Uji kesesuaian hipotesis ini terdiri dari uji t, uji F dan koefisien determinasi.

a. Uji t

Tujuan dilakukannya uji $\mathrm{t}$ adalah untuk mengetahui pengaruh variabel independent terhadap variabel dependent secara individu/parsial. Sementara variabel independent yang akan diuji antara lain terdiri dari :

1). Variabel BI Rate (X1)

Untuk mengetahui pengaruh BI Rate terhadap Indeks Harga Saham Gabungan maka dilakukan uji hipotesis secara individu.

Hipotesis yang digunakan dalam uji ini adalah:
$\mathrm{H}_{0}: \beta_{1}=0$ : Tidak ada pengaruh secara parsial antara BI Rate terhadap Indeks Harga Saham Gabungan.

$\mathrm{H}_{\mathrm{a}}: \beta_{1} \# 0$ : Ada pengaruh secara parsial antara BI Rate terhadap Indeks Harga Saham Gabungan. kriteria penoalakan bila t-hitung > ttabel

Dari hasil regresi diatas diketahui thitung : -3.678255 sedangkan signifikan yang digunakan adalah $\alpha$ : $5 \%$ df sehingga untuk pengujian $\mathrm{t}$ dengan 2 arah, signifikan 0,025\% dan df: n-k-1 (72-4-1) maka nilai ttabel yang didapatkan $0,025 \%(67)$ : $\pm 1,996$, dapat didimpulkan disimpulkan bahwa nilai $\mathrm{t}$ hitung sebesar $(-3.678255)>$ t-tabel $(-1.996)$ sehingga penolakan $\mathrm{H}_{0}$ yang berarti secara parsial BI Rate mempunyai pengaruh negatif terhadap Indeks Harga Saham Gabungan.

2). Variabel Tingkat Inflasi (X2)

Untuk mengetahui pengaruh tingkat inflasi terhadap Indeks Harga Saham Gabungan akan dilakukan uji hipotesis secara individu.

Hipotesis yang digunakan dalam uji ini adalah : 
$\mathrm{H}_{0}: \beta_{2}=0$ : Tidak ada pengaruh secara parsial antara tingkat inflasi terhadap Indeks Harga Saham Gabungan

Ha : $\beta_{2} \# 0$ : Ada pengaruh secara parsial antara tingkat inflasi terhadap Indeks Harga Saham Gabungan kriteria penolakan bila t-hitung > ttabel.

Dari hasil regresi diketahui t-hitung : - 2.375726 sedangkan signifikan yang digunakan adalah $\alpha: 5 \% \mathrm{df}$ sehingga untuk pengujian dengan 2 arah dengan signifikan $0.025 \%$ data df : n-k-1(72-4-1) maka nilai t-tabel yang didapatkan $0,025 \%$ (67) : \pm 1,996

Area penolakan $\mathrm{H}_{0}$ dapat disimpulkan bahwa t-hitung (2.375726) > t-tabel $(-1,996)$ sehingga berada didaerah penolakan $\mathrm{H}_{0}$ yang berarti secara parsial tingkat inflasi mepunyai pengaruh negatif terhadap Indeks Harga Saham Gabungan.

3). Variabel Kurs (Log X3)

Untuk mengetahui pengaruh kurs terhadap Indeks Harga Saham Gabungan akan dilakukan uji hipotesis secara individu.

Hipotesis yang digunakan dalam uji ini adalah :
$\mathrm{H}_{0}: \beta_{3}=0$ : Tidak ada pengaruh secara parsial antara kurs terhadap Indeks Harga Saham Gabungan Ha : $\beta_{3} \# 0$ : Ada pengaruh secara parsial antara kurs terhadap Indeks Harga Saham Gabungan, kriteria penolakan bila t-hitung $>\mathrm{t}$-tabel

Dari hasil regresi diatas diketahui t-hitung : $\quad-6.269700$ sedangkan signifikan yang digunakan adalah $\alpha: 5 \%$ df sehingga untuk pengujian dengan 2 arah dengan signifikan $0.025 \%$ data df : n-k-1(72-4-1) maka nilai t-tabel yang didapatkan 0,025\% (67) : $\pm 1,996$

Area penolakan $\mathrm{H}_{0}$ dapat disimpulkan bahwa t-hitung (6.269700) > t-tabel $(-1,996)$ sehingga berada didaerah penolakan $\mathrm{H}_{0}$ yang berarti secara parsial kurs mepunyai pengaruh negatif terhadap Indeks Harga Saham Gabungan.

4). Variabel Indeks Dow Jones (Log $\mathrm{X} 4)$

Untuk mengetahui pengaruh Indeks Dow Jones terhadap Indeks Harga Saham Gabungan akan dilakukan uji hipotesis secara individu.

Hipotesis yang digunakan dalam uji ini adalah : 
$\mathrm{H}_{0}: \beta_{4}=0$ : Tidak ada pengaruh secara parsial antara Indeks Dow Jones terhadap Indeks Harga Saham Gabungan.

Ha : $\beta_{4} \# 0$ : Ada pengaruh secara parsial antara Indeks Dow Jones terhadap Indeks Harga Saham Gabungan, kriteria penolakan bila thitung > t-tabel.

Dari hasil regresi diatas diketahui t-hitung : 35.28106 sedangkan signifikan yang digunakan adalah $\alpha: 5 \%$ df sehingga untuk pengujian dengan 2 arah dengan signifikan $0.025 \%$ data df : n-k-1(72-4-1) maka nilai t-tabel yang didapatkan $0,025 \%(67): \pm 1,996$.

Area penolakan $\mathrm{H}_{0}$ dapat disimpulkan bahwa niliai t-hitung $(35.28106)>$ t-tabel $(-1,996)$ sehingga berada didaerah penolakan $\mathrm{H}_{0}$ yang berarti secara parsial Indeks Dow Jones mepunyai pengaruh positif terhadap Indeks Harga Saham Gabungan.

b. Uji F

Uji F dilakukan untuk mengetahui pengaruh variabel independent terhadap variabel dependent secara serentak atau bersama-sama. Hipotesis yang digunakan adalah :

$\mathrm{H}_{0}: \beta_{1}, \beta_{2}, \beta_{3}, \beta_{4}=0$ : artinya tidak ada pengaruh secara simultan variabel terhadap BI Rate, tingkat inflasi, kurs dan Indeks Dow Jones terhadap Indeks Harga Saham Gabungan.

Ha: $\beta_{1}, \beta_{2}, \beta_{3}, \beta_{4} \neq 0$ : artinya ada/ terdapat pengaruh secara simultan variable terhadap BI Rate, tingkat inflasi, kurs dan Indeks Dow Jones terhadap Indeks Harga Saham Gabungan .

Kriteria penolakan $\mathrm{H}_{0}$ $\mathrm{H}_{0}$ ditolak jika $\mathrm{F}$ statistik $>\mathrm{F}\left(\mathrm{V}_{1}, \mathrm{~V}_{2}\right)$ Dengan $\alpha 5 \%$ (df) maka diketahui: $\mathrm{V}_{1}$ : k-1 yaitu 5-1=4 dan $\mathrm{V}_{2}$ : n-k yaitu $72-5=67$

Jadi dengan $\alpha 5 \%(4,67)$ maka nilai F-tabel adalah 3,73 dan F-hitung sebesar 549.9893 .

Hipotesis yang dapat diambil yaitu F-hitung (549.9893) > F-tabel $(3,73)$ sehingga terletak di daerah penolakan $\mathrm{H}_{0}$ artinya BI Rate, tinglat inflasi, kurs dan Indeks Dow Jones secara serentak dapat mempengaruhi Indeks Harga Saham Gabungan.

c. Koefisien Determinasi $\left(\mathrm{R}^{2}\right)$

Koefisien determinasi $\left(\mathrm{R}^{2}\right)$ dari model diatas adalah 0.970445 atau 
97,04\% hal ini menunjukkan bahwa variabel independent yang terdiri dari BI Rate, tingkat inflasi, kurs dan Indeks Dow Jones dalam menjelaskan perubahan variabel dependent Indeks Harga Saham Gabungan sebesar 97,04\% sedangkan sisanya sebesar $0,02 \%$ dijelaskan oleh variabel lain yang tidak dimasukkan dalam model estimasi.

\section{Uji Asumsi Klasik}

Pengujian asumsi klasik ini dilakukan untuk mengetahui ada tidaknya pelanggaran asumsi klasik sebagai syarat untuk dapat digunakannya pengujian hipotesis diatas pengujian asumsi kalsik ini terdiri dari uji autokorelasi, Multikorelineritas, Heterokesdasitas dan Normalitas.

\section{a. Autokorelasi}

Untuk mengetahui terjadinya korelasi serial antar variabel independent (autokorelasi) maka salah satu uji yang dapat dilakukan adalah melalui uji durbin Watson yang tersedia dalam program eviews. Hipotesis yang digunakan adalah: $\mathrm{H}_{0}: \rho=0$ : Tidak terjadi korelasi berseri antara kesalahan
Ha : $\rho$ \# 0 : Terjadi korelasi berseri antara kesalahan pengganggu atau autokorelasi

Ketentuan:

1). DW statistik > 4-dl maka terjadi autokorelasi negatif $(\rho-)$

Dengan $\alpha 1 \%$ dan df (4-1) serta $\mathrm{n}$ : 72 diketahui :

dl : 1,53 4-dl : 2,47

$\mathrm{du}: 1,70$ 4-du : 2,30

Berdasarkan hasil estimasi diatas diketahui DW statistik 1.747154 sehingga daerah penolakan $\mathrm{H}_{0}$ adalah sebagai berikut:

Berdasarkan kurva penolakan $\mathrm{H}_{0}$ diatas diketahui bahwa DW terletak diantara du dan 4-du yaitu $(1,70)<$ DW $(1.747154)<4-d u \quad(2,47)$ sehingga dapat disimpulkan bahwa model regresi diatas tidak terjadi korelasi serial antara kesalahan pengganggu atau $\mathrm{p}=0$

b. Heterokedastisitas

Pengujian heteroskedatisitas bertujuan untuk mengetahui apakah variasi residual absolut sama atau tidak sama untuk semua pengamatan. Uji heterskedaskedastisitas dapat dilakukan melalui uji White yang tersedia dalam program eviews 4.1 . 
Hipotesis yang digunakan dalam uji adalah:

$\mathrm{H}_{0}: \mathrm{E}\left(\mathrm{ei}^{2}, \mathrm{xi}^{2}\right)=0: \quad$ Tidak terjadi heteroskedastisitas

Ha : E (ei2,xi2) \# 0 : Terjadi

heteroskedastisitas

Ketentuan penolakan $\mathrm{H}_{0}$ bila $\alpha<5 \%$ Berdasarkan uji White ada 2 yaitu yang pertama no croos terms di ketahui nilai Obs*R-square sebesar 20.96625 maka dengan nilai df $X^{2}-$ hitung sebesar 31.41 sedangkan cross terms nilai Obs*R-square sebesar 29.95740 maka dengan nilai df $\mathrm{X}^{2}-$ hitung sebesar 42.55 maka dapat di simpulkan bahwa df $\mathrm{X}^{2}$ - hitung lebih besar dari pada Obs*R-square artinya tidak terjadi heteroskedastisitas.

c. Multikolinearitas

Pengujian multikolinearitas dilakukan untuk mengetahui ada tidaknya hubungan linear antara variabel independent satu dengan variabel independent lainnya. Pengujian multikolinearitas ini dilakukan melalui metode korelasi parsial. Pengujian ini terdiri atas beberapa langkah yaitu:
1). Melakukan regresi antara variabel dependent dengan variabel independent dihasilkan persamaan. $\mathrm{Y}=0.257754-0.026240(\mathrm{X} 1)-$ $0.004654(\mathrm{X} 2)-0.653985(\mathrm{LX} 3)+$ 1.492418 (LX4)

Diperoleh nilai R-squared 0.970445

2). Regresi variabel independent

a) BI Rate, tingkat inflasi, kurs dan Indeks Dow Jones dalam bentuk $\left(\mathrm{R}^{2} 11\right)$, persamaan yang dihasilkan. $\mathrm{X} 1=$ $24.81829+-0.096888 \mathrm{X} 2+$ 11.22856 LX3

\subsection{LX4}

Dari persamaan diatas dihasilkan R-squared sebesar 0.629028

b) Tingkat inflasi, BI Rate, kurs dan Indeks Dow Jones dalam bentuk $\left(\mathrm{R}^{2} 12\right)$, persamaan yang dihasilkan. X2= $7.536353-1.284829 \times 1+$ $11.05552 \quad$ LX3

\subsection{LX4}

Dari persamaan diatas dihasilkan R-squared sebesar 0.248660 .

c) Kurs, BI Rate, tingkat inflasi dan Indeks Dow Jones dalam bentuk $\left(\mathrm{R}^{2} 13\right)$, persamaan 
yang dihasilkan. LX3 = $2.634345+0.052522 \mathrm{X} 1+$ $0.003900 \mathrm{X} 2+0.242877$ LX4

Dari persamaan diatas dihasilkan R-squared sebesar 0.660596 .

d) Indeks Dow Jones, BI Rate, tingkat inflasi dan kurs dalam bentuk $\left(\mathrm{R}^{2} 14\right)$, persamaan yang dihasilkan.

$\mathrm{X} 4=-1.106685-0.089657 \mathrm{X} 1$ $+(-0.019745 \mathrm{X} 2)+1.476828$ LX3

Dari persamaan diatas dihasilkan R-squared sebesar 0.454308 .

Dari hasil regresi diatas diketahui bahwa $\mathrm{R}^{2} 1$ (0.970445) > $\mathrm{R}^{2} 11$ (0.629028), $\mathrm{R}^{2} 12$ (0.248660), $\mathrm{R}^{2} 13$ (0.660596), $\mathrm{R}^{2} 14 \quad(0.454308)$ sehingga dapat di simpulkan bahwa dalam model regresi diatas tidak terjadi multikolinearitas.

\section{Ringkasan Hasil Penelitian}

1.Pengaruh variabel Independent terhadap variabel Dependent

Berdasarkan hasil regresi dari keempat variabel bebas atau Independent yang terdiri dari BI Rate, tingkat inflasi, kurs dan Indeks Dow Jones berpengaruh dan signifikan pada masing-masing regresi, lebih dijelaskan pengaruh variabel independent terhadap variabel dependent dapat diuraikan sebagi berikut :

2. BI Rate berpengaruh negatif dan signifikan terhadap Indeks Harga Saham Gabungan

BI rate berpengaruh negatif dan signifikan terhadap indeks harga saham gabungan, yaitu ketika BI rate naik maka pengaruhnya terhadap IHSG yaitu para investor yang berinvestasi di pasar modal akan melakukan saving langsung ke BI. Hal ini berarti dapat dijelaskan bahwa jika BI Rate meningkat maka akan terjadi penurunan pada pasar saham terutama terhadap Indeks Harga Saham Gabungan yang mana investor di pasar modal memiliki keinginan untuk beralih ke sektor perbankan sehingga dengan seperti itu akan diperoleh pendapatan lebih.

3. Tingkat Inflasi berpengaruh negatif dan signifikan terhadap Indeks Harga Saham Gabungan

Pengaruh yang berbeda pula yang ditunjukkan oleh variabel tingkat inflasi, dimana tingkat inflasi mempunyai pengaruh negatif 
terhadap variabel dependent yaitu Indeks Harga Saham Gabungan. Hal ini menunjukkan bahwa adanya penurunan IHSG yang mana karena faktor inflasi dampaknya terhadap sektor pasar modal cukup fatal. Tingkat inflasi naik maka investor atau masyarakat banyak menanamkan modalnya pada sektor riil atau perusahaan bahkan membeli perusahaan yang sekiranya menguntungkan, hal ini berpengaruh terhadap pergerakan IHSG bisa jadi positif dan bisa jadi negatif karena mayoritas investor akan membeli perusahaan misalnya melalui saham perusahaan di pasar modal. Sehingga bisa jadi investor tersebut melakukan pembelian perusahaan asing atau indeks bursa asing yang menguntungkan

4. Kurs berpengaruh negatif dan signifikan terhadap Indeks Harga Saham Gabungan

Pengaruh yang berbeda pula yang ditunjukkan oleh variabel kurs, dimana kurs mempunyai pengaruh negatif terhadap variabel dependent yaitu Indeks Harga Saham Gabungan. Hal ini menunjukkan nilai kurs memicu resiko saham.
Perubahan nilai kurs timbul apabila terdapat perubahan kurs antara transaksi dan penyelesaian pos moneter yang timbul dari transaksi dalam mata uang asing.

Kurs meningkat menjadikan pergerakan Indeks Harga Saham Gabungan tersebut mengalami peningkatan / kenaikan yang signifikan karena banyak investor dari perusahaan saham asing maupun investor lokal memiliki ketertarikan untuk membeli saham lokal sehingga pasar saham bergairah dan ramai, sementara kurs melemah atau turun maka Indeks Harga Saham Gabungan akan mengalami penurunan karena investor akan keluar dari pasar saham lokal dan membeli saham asing yang lebih menguntungkan, namun ada pula investor yang berani mengambil resiko untuk membeli saham lokal pada saat kurs melemah dan akan menjualnya pada saham kurs naik, namun investor yang memiliki tekad seperti itu sangat sedikit.

Hal ini akan mempengaruhi keputusan seorang investor dalam berinvestasi. Seorang investor akan menanamkan modalnya pada 
perusahaan yang mempunyai kinerja yang baik karena dapat meningkatkan kekayaan bagi pememgang sahamnya. Kurs mata uang rupiah terhadap dollar melemah maka dampaknya terhadap IHSG adalah bisa jadi berpengaruh baik dan buruk, perusahaan asing bisa jadi keluar bahkan masuk karena adanya kurs yang melemah.

5. Indeks Dow Jones berpengaruh positif dan signifikan terhadap Indeks Harga Saham Gabungan

Pengaruh yang berbeda pula yang ditunjukkan oleh variable Indeks Harga Saham Gabungan, dimana Indeks Dow Jones mempunyai pengaruh positif terhadap variabel dependent yaitu Indeks Harga Saham Gabungan. Hal ini menunjukkan bahwa Indeks Dow Jones mempengaruhi indeks saham. lainnya di bursa saham sehingga indeks Dow Jones dapat dijadikan patokan dalam melakukan jual beli saham asing maupun saham dalam negeri. Begitu juga dampaknya terhadap IHSG, jika Indeks Dow Jones meningkat maka IHSG akan mengalami peningkatan dan sebaliknya. Sehingga dengan Indeks
Dow Jones yang pergerakannya selalu bagus maka kondisi saham juga akan bagus dapat menarik calon investor untuk bergabung atau bahkan meningkatkan jumlah investasi di pasar saham guna mencapai keuntungan di pasar saham dan mampu bersaing dengan investor-investor lainnya.

\section{KESIMPULAN}

Penelitian ini dilakukan untuk melihat tentang pengaruh BI Rate, tingkat inflasi, kurs dan Indeks Dow Jones terhadap Indeks Harga Saham Gabungan periode 2009 sampai 2014. Berdasarkan hasil analisis data dan pembahasan maka dapat diambil kesimpulan sebagai berikut :

1. Berdasarkan hasil regresi berganda maka dapat disimpulkan bahwa BI Rate berpengaruh negatif dan signifikan terhadap Indeks Harga Saham Gabungan dengan koefisien sebesar - 0.026240, artinya apabila BI Rate naik sebesar 1\% maka Indeks Harga Saham Gabungan akan turun sebesar $-0.026 \%$.

2. Tingkat inflasi berpengaruh negatif dan signifikan terhadap Indeks Harga Saham Gabungan dengan koefisien 
regresi sebesar - 0.004654, artinya apabila tingkat inflasi naik sebesar 1\% maka Indeks Harga Saham Gabungan akan turun sebesar $0.004 \%$.

3. Kurs berpengaruh negatif dan signifikan terhadap Indeks Harga Saham Gabungan dengan koefisien regresi sebesar - 0.653985, artinya apabila kurs naik sebesar $1 \%$ maka Indeks Harga Saham Gabungan akan turun sebesar $-0.653 \%$.

4. Indeks Dow Jones berpengaruh positif dan signifikan terhadap Indeks Harga Saham Gabungan dengan koefisien regresi sebesar 1.492418, artinya apabila Indeks Dow Jones naik sebesar 1\% maka Indeks Harga Saham Gabungan akan naik sebesar $1.492 \%$.

\section{SARAN}

Berdasarkan kesimpulan diatas maka saran-saran yang dapat diberikan melalui hasil penelitian ini yaitu :

1. Meningkatnya BI rate terbukti menyebabkan beberapa investor melakukan saving ke BI langsung. Oleh karena itu patut diwaspadai ketika BI rate naik akan mengurangi investor yang melakukan investasi di pasar modal karena pasti akan memberikan pengaruh yang sebaliknya sehingga membuat pasar modal mengalami gangguan. Bagi investor disarankan untuk mengawasi pergerakan BI rate karena akan sangat berpengaruh terhadap indeks saham terutama Indeks Harga Saham Gabungan

2. Karena pada penelitian ini variabel yang berpengaruh terhadap Indeks Harga Saham Gabungan sangat terbatas perlu ditambah lagi variabel lain yang berpengaruh pula, maka untuk mengembangkan penelitian ini disarankan untuk penelitian selanjutnya agar menggunakan variabel lainnya, karena kemungkinan adanya respon yang tidak langsung.

3. Untuk mengembangkan penelitian selanjutnya disarankan untuk melihat pengaruh variabel makro ekonomi lainya secara terperinci yang dapat berpengaruh dan menggunakan variabel lainnya diluar variabel moneter seperti keadaan sosial politik suatu 
negara. Dan juga disarankan untuk melakukan penelitian dengan menggunakan pendekatan lainnya.

\section{DAFTAR PUSTAKA}

Abbas Valadkhani, Surachai Chancharat and Charles Havie, 2006, "The Interplay Between the Thai and Several Other International Stock Markets". Available:

www.ideas.repec.org

Ardian, Witjaksono Agung. 2010. Analisis Pengaruh Tingkat Suku Bunga SBI, Minyak Dunia, Harga Emas Dunia, Kurs Rupiah, Indeks Nikkei 225, dan Indeks Dow Jones Terhadap IHSG. Tesis. Universitas Diponegoro: Semarang.

Fakultas Ekonomi dan Bisnis. 2013. Buku Pedoman Penulisan Skripsi dan Tugas Akhir. Malang: UMM.

Fitriawati. 2009. Pengaruh Uang Yang Beredar (M2), Kurs, Inflasi Dan Tingkat Suku Bunga SBI Terhadap Beta Saham Syariah (JII) dan Indeks Harga Saham Gabungan (IHSG). Universitas Syarif Hidayatullah Jakarta: Jakarta.

Halim, Abdullah. 2005. Analisis Investasi, Edisi 2. Salemba Empat : Jakarta.
Hismendi, dkk, 2013. Aanalisis Pengaruh Nilai Tukar, SBI, Inflasi Dan Pertumbuhan GDP Terhadap Pergerakan Indeks Harga Saham Gabungan di Bursa Efek Indonesia. Tesis. Universitas Syah Kuala: Banda Aceh.

Kuncoro, Mudrajad. 2010. Metode Penelitian dan Riset. Salemba: Jakarta.

Mankiw, N. Gregory, Estown Quah, dan Peter Wilson, 2012, Pengantar Ekonomi Makro Edisi Asia, Salemba Empat, Jakarta.

Mansur, Moh. 2005. Pengaruh Indeks Bursa Global terhadap Indeks Harga Saham Gabungan (IHSG) pada Bursa Efek Jakarta (BEJ) Periode Tahun 2000-2002. Sosiohumaniora, Vol. 7, No. 3, November.

Pasaribu, Rowland Bismark Fernando, 2014. Pengaruh Suku Bunga SBI, Inflasi, IHSG Terhadap Tingkat Pengembalian Reksa Dana Saham. Jurnal Akuntasi dan Manajemen, Universitas Gunadarma:Yogjakarta.

Sharpe, William F, G.J. Alexander, and J.V. Bailey. 1997. Investasi. Singapore : Prentice Hall.

Sofyan, Ahmad. 2009. Analisis Perbandingan Produk Reksa Dana Sebagai Dasar Perimbangan Berinvestasi Dengan Menggunakan Tolok 
Ukur Indeks Harga Saham

Gabungan (IHSG) dan Nilai

Sertifikat Bank Indonesia (SBI). Skripsi. Universitas Gunadarma: Yogjakarta.

http://id.wikipedia.org/wiki/IHSG

(Diakses tanggal 4 Mei 2015 pukul 19.51 WIB.

www.idx.co.id Diakses tanggal 4 Mei 2015 pukul 19.30 WIB.

www.bi.go.id Diakses tanggal 10 Mei 2015 pukul 15.40 WIB. 